\title{
STRESS IN FARM ENTREPRENEURS
}

This is a draft chapter. The final version is available in 'Handbook of Stress in the Occupations' edited by Janice Langan-Fox and Cary L. Cooper, published in 2011, Edward Elgar Publishing Ltd. doi:10.4337/9780857931153

The material cannot be used for any other purpose without further permission of the publisher, and is for private use only.

The book chapter reference:

Kallioniemi, Marja, Simola, Ahti, Kinnunen, Birgitta \& Kymäläinen, Hanna-Riitta 2011. Stress in Farm Entrepreneurs. In: Langan-Fox, Janice \& Cooper, Cary L. (Eds.) Handbook of Stress in the Occupations. pp. 385-406. Cheltenham, UK and Northampton, MA, USA: Edward Elgar Publishing. doi:10.4337/9780857931153

\section{Acknowledgments}

The final publication, editors Janice Langan-Fox and Cary L. Cooper, publisher Edward Elgar Publishing and co-authors Ahti Simola, Birgitta Kinnunen and Hanna-Riitta Kymäläinen are gratefully acknowledged.

Address for correspondence:

Marja Kallioniemi

Research Scientist, PhD

Natural Resources Institute Finland (Luke)

Bioeconomy and environment

e-mail: marja.kallioniemi@luke.fi

phone: +35829532 6207

address: Luke c/o University of Aalto,

PL 15600, FI-00076 Aalto, Finland

www.luke.fi 


\section{Stress in farm entrepreneurs}

Authors:

Marja K. Kallioniemi, MTT Agrifood Research Finland, Economic Research

Ahti Simola, Finnish Institute of Occupational Health, Work Organizations

Birgitta Kinnunen, Finnish Institute of Occupational Health, Health and Work Ability, National

Centre for Agricultural Health

Hanna-Riitta Kymäläinen, University of Helsinki, Department of Agrotechnology

\section{Current features and characteristics of agriculture}

Agriculture is an old and traditional occupational sector that utilizes natural resources. The rural environment is sometimes characterized as a peaceful living environment. Today, the operational environment of farm entrepreneurs also includes economic and political decisions. The circumstances of farm enterprises can perhaps be explained by the historical background of society. On a farm, technological equipment and development, buildings and social relationships with other workers are also part of the farm entrepreneur's everyday life. The operational environment of farmers with these diverse features may affect their well-being. Here, we briefly describe the current situation faced by farmers in this first section, since it enables an understanding of stress and stressors among this occupational group.

In recent years, changes in the international agricultural product market have been rapid due to both random and structural causes (Niemi, 2009a). The most significant processes currently influencing the world economy are globalization processes (Becvarova, 2008; TNS Opinion \& Social, 2010). Economic development, at least in the member countries of the European Union (EU), is significantly influenced by external factors and processes related to the changes in the world economy that also affect the agricultural sector (Becvarova, 2008). We use Finland in this chapter as an example, although international studies are additionally reviewed.

Finland has experienced a rapid structural change in the agricultural sector since 1995, when the country joined the European Union (EU). According to Niemi (2009b), during 1995-2008 almost a third (32\%) of Finnish farms ceased agricultural production. During the same period, the average field size on farms increased by 50\% to 34 hectares (Väre, 2009). Such rapid changes, for instance in field sizes, have been significant and unique within Finnish society, and also within the European context (Enroth et al., 2003). Despite these changes, Finnish agriculture still remains based on family farming: $88 \%$ of all farms are owned by individuals or families (Väre, 2009), and family members still perform most (84\%) of the work on farms (Information Centre of the Ministry of Agriculture and Forestry, 2009). The term 'farmer' is used here as a synonym of 'farm entrepreneur'. Vesala and Vesala (2008) consider current agricultural policy to emphasize the improvement of competitiveness, and 'entrepreneurship' is a key factor in achieving this aim. A Finnish follow-up survey in $2001(\mathrm{n}=898)$ and $2006(\mathrm{n}=740)$ included both traditional and diversified farmers (Vesala and Vesala, 2008). In both surveys the majority (75\%) of traditional farmers and nearly all $(90 \%)$ diversified farmers identified themselves, at least to a certain extent, as 
'entrepreneurs'. Young farmers chose the identity of 'entrepreneur' more often than older farmers. The dominant production lines are crop production (64\% in 2008) and dairy husbandry (19\%) (Väre, 2009). However, if support (41\%) is excluded, milk production (22\%) and other livestock $(15 \%)$ accounted for the greatest proportion of returns from agriculture (Karhula and Turunen, 2009). Finnish agricultural policy lies in the support schemes set down in the Common Agricultural Policy of the EU. These include direct payments funded by the EU and the co-funded natural handicap and agri-environmental payments, which are further supplemented by national aids (Vihinen, 2004). The EU markets for agricultural products are steered by administrative means, similarly to many other industrialised countries (Niemi, 2009b). Currently, a significant proportion of farm and horticultural income (43\% in 2009) comes from subsidies. Before Finland joined the EU in 1995, this share was below $20 \%$ (Niemi, 2010). Political decisions are often difficult for farmers to predict, which may affect their management of work and stress.

In recent years there has been a decreasing trend in agricultural income in Finland. For example, in 2004 the coefficient of profitability was 22\% lower than in 1992 (Kettunen, 1994; Niemi and Ahlstedt, ed., 2006). New challenges in agriculture have encouraged farm families to seek alternative sources of livelihood (Rantamäki-Lahtinen, 2009). While the number of traditional agricultural farms as rural enterprises has declined by $22 \%$ during recent years (2000-2007), the number of diversified farms has increased by $6 \%$, and the number of rural enterprises with no link to agriculture has increased by $23 \%$. Diversified farms operate in a variety of sectors, e.g. services such as contracting and tourism, industries such as food and wood processing, and the production of renewable energy. In some other European countries, the proportion of diversified farms is also over 20\%, for instance in Sweden, Norway, Germany, France and the UK (Rantamäki-Lahtinen, 2009).

One important random cause of changes in the agricultural market is exceptional weather conditions, which in many agricultural regions globally are a major cause of variations in agricultural outputs (Niemi, 2009a). Climate change is expected to severely affect agriculture. There is a need to define the appropriate adaptation strategies to cope with risks associated with changes in temperatures, rainfall and drought periods, depending on the area and location of the country (Moriondo et al., 2010; Tirado et al., 2010). Finland's most important agricultural regions are in southern and south-western parts of the country, between $60-62^{\circ} \mathrm{N}$. Finland represents the uppermost extreme for field crop production: the most typical features are harsh winters, intensive and rapid rates of development due to exposure to long days and rapidly increasing mean temperatures, cool mean temperatures during the growing season, and the risk of night frosts, early summer drought and of abundant precipitation close to harvest (Peltonen-Sainio et al., 2009).

In addition to the weather conditions, the prices of agricultural products have been influenced by the growing demand for cereals to be used as raw materials for biofuel. According to Smyth et al. (2010), biofuel may have the potential to become an economically viable alternative for both farmers and consumers. However, the increased demand for food is a long-term global trend that will continue far into the future (Niemi, 2009a). Furthermore, there is increasing global and local discussion about other topics related to food production and thus to farming, such as sustainability 
(Kerney, 2010) and ethics in food production, particularly animal welfare (Broom, 2010). According to TNS Opinion \& Social (2010), the intensification of farming, such as the use of pesticides, is of interest to many consumers, which may place further pressure on farmers. New technologies such as genetically modified organisms (GMOs), nanotechnology and animal cloning will alter current and future agriculture and food production.

The economic situation, environmental development and incidents, as well as consumer trends in society, all mean that farmers do not have a stable future, but must face several different demands and signals. These changes and features clearly have a connection to well-being among farmers. It is important to understand the operational environment when considering the life and work of farmers and the factors that affect them. These factors may also act as stressors.

In Finland, the findings of studies on occupational health among farmers have not been very positive. Saarni et al. (2008) reported that farmers had the lowest rates in all factors measured when comparing their work ability, subjective quality of life and health-related quality of life with that of salary earners and other entrepreneurs. Furthermore, in a study by the Finnish Ministry of Employment and the Economy (Peltoniemi, 2005), the work ability of farm entrepreneurs was similarly $10 \%$ lower on average than among salary earners and other entrepreneurs. Psychosocial problems such as high demands combined with a lack of support and control were suggested by Saarni et al. (2008) to describe the situation of Finnish agriculture. Peltoniemi (2005) noted the uncertain future of farming, long working days and the typically rather physical and strenuous work. Kallioniemi et al. (2009) observed in their study on Finnish full-time farm entrepreneurs that $34 \%$ reported symptoms that could be classified as those of exhaustion.

\section{Farming and stress}

\section{Studies concerning stress in farming}

Stress is usually defined as a developing conflict between the possibilities and demands of the environment and the worker's own expectations, resources and capacities (Karasek and Theorell, 1990). The National Institute for Occupational Safety and Health completed this definition, adding that stress is a 'harmful and emotional response' to the mentioned unbalance (NIOSH, 1999). The demands of work circumstances may exceed the worker's capability to cope with or control these features (Leka and Cox, 2008). Previous international and national research results concerning stress symptoms among farm entrepreneurs have been variable (Table 1). Different methods have been in use to measure and research stress symptoms and feelings, which probably partly explains the different observations recorded. Therefore, the results of these studies are not directly comparable. 
Table 1. Results on stress among farm entrepreneurs from previous studies.

\begin{tabular}{|c|c|c|c|c|}
\hline Study & $\begin{array}{l}\text { Country and } \\
\text { area/target }\end{array}$ & Sample size, $n$ & Method & Results concerning stress \\
\hline $\begin{array}{l}\text { Walker and } \\
\text { Walker, } 1988\end{array}$ & $\begin{array}{l}\text { Canada; } \\
\text { Manitoba }\end{array}$ & $\begin{array}{l}613 \text { farmers } \\
\text { and } 109 \text { urban } \\
\text { residents }\end{array}$ & $\begin{array}{l}\text { Self-reported } \\
\text { prevalence of } 19 \\
\text { stress-related } \\
\text { symptoms }\end{array}$ & $\begin{array}{l}\text { Means for total stress } \\
\text { symptom scores: } \\
37 \% \text { among farmers, } \\
30 \% \text { among urban residents }\end{array}$ \\
\hline $\begin{array}{l}\text { Deary et al., } \\
1997\end{array}$ & UK farmers & 318 farmers & $\begin{array}{l}\text { Survey during a } \\
\text { farm show; } \\
\text { Edinburgh } \\
\text { Farming Stress } \\
\text { Inventory }\end{array}$ & $\begin{array}{l}\text { Based on work-related } \\
\text { stress domains: rather 'high } \\
\text { amounts' of stress reported } \\
\text { on some domains }\end{array}$ \\
\hline $\begin{array}{l}\text { Booth and } \\
\text { Lloyd, } 1999\end{array}$ & $\begin{array}{l}\text { England; } \\
\text { South-West }\end{array}$ & $\begin{array}{l}303 \text { replies; } \\
271 \text { men and } \\
32 \text { women }\end{array}$ & $\begin{array}{l}\text { Postal survey; } \\
\text { Hospital } \\
\text { Anxiety } \\
\text { Depression } \\
\text { Scale }\end{array}$ & $\begin{array}{l}\text { Results confirm 'the high } \\
\text { levels of perceived stress' } \\
\text { and 'higher levels of stress' } \\
\text { than in general in society }\end{array}$ \\
\hline $\begin{array}{l}\text { Ristiluoma } \\
\text { and Sipiläinen, } \\
2003\end{array}$ & $\begin{array}{l}\text { Finland; } \\
\text { profitability } \\
\text { accounting } \\
\text { farms }\end{array}$ & 555 farms & Postal survey & $\begin{array}{l}\text { In farm work, } 55 \% \text { of } \\
\text { respondents experienced } \\
\text { stress }\end{array}$ \\
\hline Melberg, 2003 & $\begin{array}{l}\text { Norway, } \\
\text { farm spouses }\end{array}$ & $\begin{array}{l}1408 ; \\
704 \text { men and } \\
704 \text { women }\end{array}$ & $\begin{array}{l}\text { Indicators of } \\
\text { stress; } 9 \\
\text { variables }\end{array}$ & $\begin{array}{l}\text { Indications: farmers may } \\
\text { have been capable to 'adapt, } \\
\text { handle and resist' work } \\
\text { stress. }\end{array}$ \\
\hline $\begin{array}{l}\text { Alpass et al., } \\
2004\end{array}$ & $\begin{array}{l}\text { New Zealand, } \\
\text { dairy farmers }\end{array}$ & $\begin{array}{l}985 ; \\
860 \text { men and } \\
125 \text { women }\end{array}$ & $\begin{array}{l}\text { Postal survey; } \\
\text { 12-item severity } \\
\text { of stress scale, } \\
\text { frequency of } \\
\text { stress }\end{array}$ & $\begin{array}{l}\text { The prevalence of stress } \\
\text { was 'moderate' }\end{array}$ \\
\hline $\begin{array}{l}\text { Simpson et al., } \\
2004\end{array}$ & $\begin{array}{l}\text { Canada, } \\
\text { Ontario }\end{array}$ & $\begin{array}{l}2946 \text { couples } \\
\text { from } 2693 \\
\text { farms }\end{array}$ & $\begin{array}{l}\text { The Ontario } \\
\text { Farm Family } \\
\text { Health Study }\end{array}$ & $\begin{array}{l}18 \% \text { of men and } 11 \% \text { of } \\
\text { women answered that their } \\
\text { life was 'very stressful' }\end{array}$ \\
\hline
\end{tabular}

The Fourth European Working Conditions Survey (Parent-Thirion et al., 2007) revealed that among skilled agricultural and fishery workers, the level of stress (32\%) was the highest among the different occupation sectors examined. This study also recorded the largest percentage growth in the stress level among farm and fishery workers compared to data from 2000 . The average prevalence of stress among all occupations was $23 \%$ among men and $21 \%$ among women. In a Finnish postal survey, including responses from 555 farms (Ristiluoma and Sipiläinen 2003), over half (55\%) of farmers experienced stress in farm work. Alston (2004) described the situation in Australia, where rural areas suffer from 'an own form of stress': services and working opportunities are diminishing, poverty is increasing and young people are moving away from the countryside. Alston was worried about 'neoliberal' policies, which together with economic factors may leave farm families without 
support. On the other hand, Melberg (2003) considered in her study that. in general, Norwegian farm entrepreneurs are not vulnerable to stress symptoms. Work and life on a farm include positive elements such as fresh air, work with farm animals, freedom and independence. Farm entrepreneurs are masters of their own work. Kallio (1997) also found positive elements in farm work: a farmer has the possibility to see the results of his or her own work, and the natural environment is a special working environment.

In Finland, the Finnish Institute of Occupational Health (FIOH) has carried out rather extensive studies every third year to investigate the working conditions among the Finnish working population in general (e.g. Piirainen et al., 1997; Perkiö-Mäkelä et al., 2006a) (Table 2). The working conditions of Finnish farm entrepreneurs have been assessed by the FIOH five times during recent decades, namely in 1979, 1982, 1986, 1992 and 2004 (Rissanen ed., 2006). A wide variety of questions about working conditions have been asked, including a question about work stress. A somewhat similar question about stress (Elo et al., 2003) has been used in several other studies in Finland. In this question, the interviewer defines stress to the respondent as a situation where a person feels exited, anxious, irritated or distressed or where she/he has difficulties sleeping because matters are constantly on her/his mind. After this definition, the interviewer asks if the respondent has felt this kind of stress at the time of the interview. The validity of this 'single-item measure of stress symptoms' has been assessed, focusing on four independent data sets. Elo et al. (2003) concluded that several item scales concerning work stress could be replaced with this question, because it was assessed as satisfactory in terms of its content, criterion and construct validity.

Table 2. Studies in Finland on the prevalence of stress.

Note: The prevalence of stress has been calculated as the percentage of respondents who reported feeling some, quite a lot or a great deal of stress.

\begin{tabular}{lllll}
\hline Study & Target & $\begin{array}{l}\text { Number of farmer } \\
\text { respondents }\end{array}$ & Method & $\begin{array}{l}\text { Prevalence of } \\
\text { stress (\%) }\end{array}$ \\
\hline $\begin{array}{l}\text { Pråhl-Ollila, } \\
1995\end{array}$ & $\begin{array}{l}\text { Farm } \\
\text { entrepreneurs, age } \\
\text { under 40 years }\end{array}$ & 761 farmers & Postal survey & 64 \\
\hline $\begin{array}{l}\text { Pråhl-Ollila, } \\
1997\end{array}$ & $\begin{array}{l}\text { Random sample of } \\
\text { farm entrepreneurs }\end{array}$ & 483 farmers & Postal survey & 66 \\
\hline $\begin{array}{l}\text { Piirainen et al., } \\
1997\end{array}$ & $\begin{array}{l}\text { Finnish working } \\
\text { population }\end{array}$ & $\begin{array}{l}\text { Including 166 farm } \\
\text { entrepreneurs }\end{array}$ & $\begin{array}{l}\text { Cross-sectional, } \\
\text { telephone survey }\end{array}$ & 43 \\
\hline $\begin{array}{l}\text { Simola, 2006; } \\
\text { Kallioniemi et } \\
\text { al., 2008 }\end{array}$ & $\begin{array}{l}\text { Finnish full-time } \\
\text { farm entrepreneurs }\end{array}$ & $\begin{array}{l}1182 ; \text { including } \\
\text { 911 men and 271 } \\
\text { women }\end{array}$ & $\begin{array}{l}\text { Cross-sectional, } \\
\text { telephone survey }\end{array}$ & 34 \\
\hline $\begin{array}{l}\text { Perkiö-Mäkelä } \\
\text { et al., 2006a }\end{array}$ & $\begin{array}{l}\text { Finnish working } \\
\text { population }\end{array}$ & $\begin{array}{l}\text { Including 75 farm } \\
\text { entrepreneurs }\end{array}$ & $\begin{array}{l}\text { Cross-sectional, } \\
\text { telephone survey }\end{array}$ & 30 \\
\hline $\begin{array}{l}\text { Palmgren et al., } \\
\text { 2010 }\end{array}$ & $\begin{array}{l}\text { Women } \\
\text { entrepreneurs in }\end{array}$ & $\begin{array}{l}\text { Including 104 farm } \\
\text { women }\end{array}$ & $\begin{array}{l}\text { Postal survey } \\
\text { entrepreneurs }\end{array}$ & 57 \\
\hline
\end{tabular}


It is interesting that since Finland joined the European Union, over half (64\% and 66\%) of farmers have reported experiencing stress in two postal surveys (Pråhl-Ollila, 1995, 1997). Vihinen (2004) described how EU membership has completely changed the economic and political environment of agriculture in Finland; the prices and agricultural policy changed overnight. A recent postal survey (Palmgren et al., 2010) that solely focused on female entrepreneurs in Finland $(n=1204)$ recorded a relatively high stress prevalence of $57 \%$ among those working in agriculture and forestry $(n=104)$.

In 2004, the FIOH carried of a computer-assisted telephone interview that reached 1182 full-time farmers, including 271 (23\%) women and 911 (77\%) men (Rissanen ed., 2006). The sample was representative in terms of farm size, regional distribution and production sector, but the average field size in the sample (44 hectares) and average number of cows (21) on dairy farms were greater than on average in Finland. In addition, the number of female respondents should have been greater. One third (34\%) of the respondents in this study reported experiencing some, quite a lot or a great deal of stress at the time of the interview. The results of a 2003 survey among the Finnish working population $(n=2335)$ (Piirainen et al., 2003) were used as a reference sample, where a similar method was used. Comparison revealed that full-time farm entrepreneurs experienced a lower level of stress than the Finnish working population in general (44\%). Particularly among the oldest farm entrepreneurs group (age 55-64 years), the stress level was clearly (28\%) lower than among the working population in the oldest age group (44\%) (Kallioniemi et al., 2008). The finding of a relatively low level of stress may indicate that those who have continued within the agricultural sector have the capacity to handle and cope with stressful situations.

Binary logistic regression was carried out to determine which predictor variables were associated with the prevalence of stress (Kallioniemi et al., 2008) (Figure 1), and revealed that social relationships had the clearest association. Even today, farm families may have other members in addition to the core family, such as grandparents or unmarried siblings. A study among American farm women (Berkowitz and Perkins, 1985) also reported that stress symptoms were associated with the level of support from the spouse and with the respondents' satisfaction with their marriage. In addition to the rapid structural change in Finland, other processes have occurred in rural villages such as a decline in communality (Leskinen, 2004) and changes in rural people's conception of the family from family-centred towards more individual views (Katila, 2000; Sulin, 2001; Leskinen, 2004). Education to a university or college level was also associated with stress symptoms among the respondents (Kallioniemi et al., 2008). Possible reasons may be that more educated farm entrepreneurs are more conscious of the demands and future of the agricultural sector, and their education may provide skills to handle and perceive stress symptoms. Some respondents may have an education in a profession other than agriculture, which may cause conflicts. For example, women often work on a farm as a consequence of marriage to a farmer. However, in a Norwegian study, the stress level was lower among respondents who had a higher educational level (Melberg, 2003). Physical stress factors include illness or injury certified by doctor and a low self-estimation of the ability to work (Kallioniemi et al., 2008). According to Perkiö-Mäkelä et al. (2006b), over a third (39\%) of farm entrepreneurs reported a long-term illness or injury certified by a doctor, and 
especially among farm women the prevalence of illnesses (44\%) had increased compared to the situation in 1992. A negative attitude towards the EU has also been associated with stress. In addition, according to un-adjusted odds ratios, divorce or the ending of cohabitation, slight, moderate or high physical strenuousness of farm work and a satisfactory, adequate or poor economic situation were also variables associated with the prevalence of stress (Kallioniemi et al., 2008).

The Canadian website 'CareerCast' (www.careercast.com) ranks 200 professions from the best to the worst (Strieber, 2010). The ranking includes five main 'core criteria': the work environment, physical demands, stress, income and hiring outlook. It is interesting that dairy farming is among the ' 10 worst jobs of 2010 ', ranked number 4 . The only jobs ranked as worse than being a dairy farmer were those of a roustabout, lumberjack and ironworker. The stress points for dairy farmers were at a high level. For example, the physical demands, stamina required, outdoor work and hazards encountered were among the 21 factors possibly evoking stress, which are obviously familiar to dairy farmers.

Severe stress, often combined with other factors such as distress, social isolation or personal tragedy, may lead to suicide. In a literature review, Monk (2000) reported increasing stress and suicides among farming communities, and Patil and Somasundaram (2010) have also described suicides among farmers as a global challenge. A review of the literature reveals that the situation differs between countries, but at least in Australia (Yip et al., 2000), the UK (Meltzer et al., 2008), China (Kong and Zhang, 2010), India (Patil and Somasundaram (2010) and the USA (Gunderson et al., 1993), farm entrepreneurs have an elevated risk of suicide. In Australia, the suicide rate among rural men was observed to be higher than among urban men, but urban women had a greater suicide rate than rural women (Yip et al., 2000). Judd et al. (2006) investigated the factors that increase the risk of suicide among Australian farmers. They concluded that farmers face many stressors, but they have little 'capacity to acknowledge or express' stressors or mental health problems. In a study on the mental health of UK farmers $(n=425)$, the farmers reported less psychiatric morbidity, but they thought more often that 'life is not worth living' (Thomas et al., 2003). A later study provided information on death registrations in England and Wales from 2001-2005, when agricultural workers had the second highest proportional mortality ratio among all suicide cases after health professionals (Meltzer et al., 2008). These occupational groups both have access to suicide methods and knowledge of how to take their own life. Kong and Zhang (2010) reported that suicides in China are three- to five-fold more common in rural areas than in urban districts, and in rural areas pesticide poisoning is a common method for committing suicide. In a study from Finland (Koskinen et al., 2002) analyzing 1359 suicides during 1988-1999, farmers had a significant peak of suicides during the spring, at the start of the growing season. Farmers also used more violent methods such as shooting and hanging than other victim groups. Isometsä et al. (1997) compared urban and rural suicides (229 cases) in Finland: rural suicide victims typically did not have a close companion and they had physical disorders, while urban victims had experienced a recent separation. Again, social relationships were revealed to be important factors. 


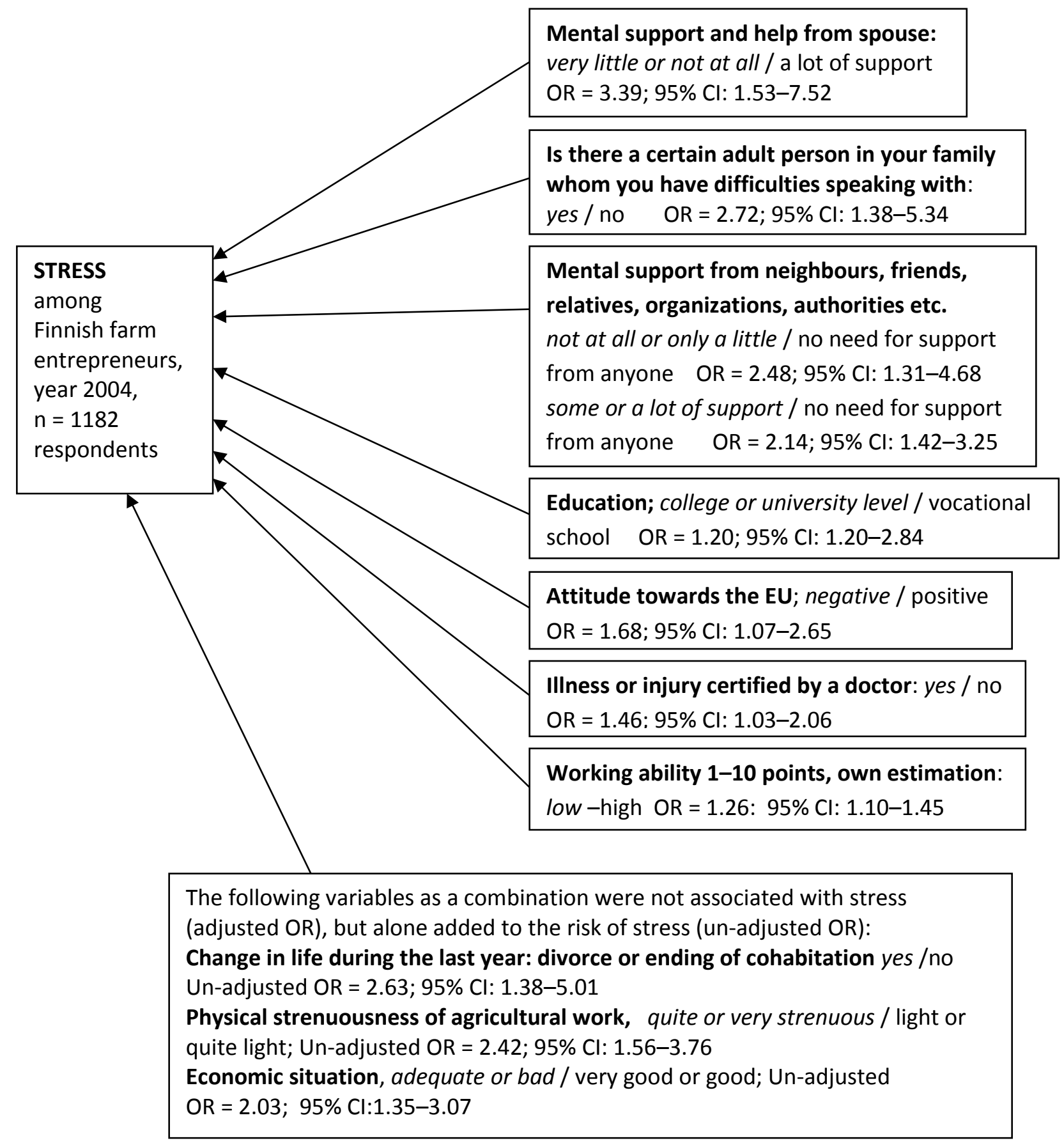

Figure 1. Associations with the response variable stress and predictor variables according to logistic regression analysis. Note: OR indicates the odds ratios and CI the confidence intervals.

Source: Kallioniemi et al., 2008.

It is well known that rural people do not always actively seek help for their mental health problems (Sulin, 2001; Gregoire, 2002; Parry et al., 2005; DeArmond et al., 2006; Judd et al. 2006; Fuller et al., 2007). The rural culture often values self-sufficiency, and other people may simply have a negative attitude towards problems related to mental health. Thus those trying to seek help may feel 
shame and may be socially stigmatized (Fuller et al., 2007). It has been recognized that various other professionals such as extension workers visiting a farm may find the farm entrepreneur to be struggling with her or his mental health problems (Sulin, 2001).

\section{Stressors among farm entrepreneurs}

We gathered information from the existing scientific literature on stressors related to agriculture. From 16 different reports, 28 stress elements were identified, indicating a relatively wide variety of stressors. Some of these stressors related to the local agricultural situation in a particular country or area, such as an animal disease crisis (Parry et al., 2005). We categorised stressors among farm entrepreneurs from different studies in Table 3 into six groups presented by NIOSH (1999). We added one group, 'personal stressors', to allow the placing of all stressors from the reference sources. The three most frequently mentioned stressors are numbered from 1 to 3 .

Stressors related to regulations, farming bureaucracy, the amount of paper work, the political framework related to agriculture, as well as those stressors related to the farm economy were the most often mentioned, being included in seven reports. In Finland, subsidies represent a significant income source for farms, and this situation has increased the number of regulations and different control systems. Simpson et al. (1998) reported that farmers had difficulties in understanding forms and they had problems with paper work. According to a Finnish expression, 'a pencil is a heavier tool for a farmer than a manure fork'. Currently, there is ongoing discussion of how administrative language is still too difficult for ordinary citizens to understand (Eloranta, 2010). As a returnee to Finland, Wager (2008) wrote in her dairy about distressing discussions with farmers concerning the control system for subsidies; the system was assessed as inhuman and alienated from reality where supervisors are afraid of their own supervisors and farmers are left alone to deal with the regulations. The Ministry of Agriculture and Forestry (2008) has tried to simplify the subsidy and control systems, for instance by providing a possibility to apply for subsidies electronically via the Internet. Even the Ministry concedes that the subsidy system is still 'very complicated'.

A poor economic situation is likely to impact on a farm entrepreneur's life in various ways, including the opportunities for family members. In addition, the ongoing structural change in agriculture, with demands for more efficient production and enlargement of farm production, may in practice mean further investments by farmers, and therefore weaken their economic situation. The weather, natural conditions and the dangers of farm work can be assessed as long-term stressors, which have been stress elements for as long as humans have cultivated land. In addition, new legislation and dangers in farm work, such as injuries and deficiencies in the work environment, were also often mentioned stressors. 
Table 3. Grouping of work conditions that may lead to stress according to NIOSH (1999). Note: The table includes stressors among farm entrepreneurs and reference sources from the scientific literature. The three most often mentioned stressors are numbered (1-3).

\begin{tabular}{|c|c|c|}
\hline $\begin{array}{l}\text { Grouping of work } \\
\text { conditions NIOSH } \\
\text { (1999) }\end{array}$ & $\begin{array}{l}\text { Stressor among farm } \\
\text { entrepreneurs }\end{array}$ & References \\
\hline \multirow[t]{6}{*}{ The Design of Tasks } & Time pressure & $\begin{array}{l}\text { Deary et al., 1997; Alpass et al., 2004; } \\
\text { Glasscock et al., 2006 }\end{array}$ \\
\hline & $\begin{array}{l}\text { Workload during intensive } \\
\text { seasons }\end{array}$ & Parry et al., 2005; Firth et al., 2007 \\
\hline & Work overload & $\begin{array}{l}\text { Ristiluoma and Sipiläinen, 2003; } \\
\text { Parry et al., 2005; Glasscock et al., } \\
2006\end{array}$ \\
\hline & Work delays & Glasscock et al., 2006 \\
\hline & $\begin{array}{l}\text { Increased technology and } \\
\text { machinery use }\end{array}$ & $\begin{array}{l}\text { Walker and Walker, 1987; Gregoire, } \\
2002\end{array}$ \\
\hline & Machinery breakdowns & $\begin{array}{l}\text { Alpass et al., 2004; Glasscock et al., } \\
2006\end{array}$ \\
\hline \multirow[t]{3}{*}{ Management Style } & $\begin{array}{l}\text { (1) Regulation, farming } \\
\text { bureaucracy, the amount of } \\
\text { paper work, the political } \\
\text { framework related to } \\
\text { agriculture }\end{array}$ & $\begin{array}{l}\text { Deary et al., 1997; Simkin et al., 1998; } \\
\text { Booth and Lloyd, 1999; Ristiluoma } \\
\text { and Sipiläinen, 2003; Alpass et al., } \\
\text { 2004; Parry et al. 2005; Glasscock et } \\
\text { al., 2006 }\end{array}$ \\
\hline & $\begin{array}{l}\text { Dealing with workers' } \\
\text { compensation }\end{array}$ & Firth et al., 2007 \\
\hline & $\begin{array}{l}\text { Lacking knowledge } \\
\text { about how to run a farm }\end{array}$ & Keating, 1987 \\
\hline \multirow{3}{*}{$\begin{array}{l}\text { Interpersonal } \\
\text { Relationships }\end{array}$} & Structure of the farming family & May, 1998a; Parry et al. 2005 \\
\hline & Isolation & Deary et al., 1997; Gregoire, 2002 \\
\hline & $\begin{array}{l}\text { Shrinking social networks, } \\
\text { social conflicts }\end{array}$ & Raine, 1999 \\
\hline Work Roles & Role conflicts & $\begin{array}{l}\text { Keating, 1987; Parry et al., 2005; } \\
\text { Glasscock et al., } 2006\end{array}$ \\
\hline \multirow[t]{6}{*}{ Career Concerns } & (1) Farm economy & $\begin{array}{l}\text { Deary et al., 1997; May,1998a; } \\
\text { Simkin et al., 1998; Melberg, 2003; } \\
\text { Ristiluoma and Sipiläinen, 2003; Parry } \\
\text { et al., 2005; Glasscock et al., 2006 }\end{array}$ \\
\hline & (3) New legislation & $\begin{array}{l}\text { Simkin et al., 1998; Booth and Lloyd, } \\
\text { 1999; Parry et al., 2005; Firth et al., } \\
2007\end{array}$ \\
\hline & Demands related to work & Keating, 1987 \\
\hline & Efficiency demands & Gregoire, 2002 \\
\hline & $\begin{array}{l}\text { Uncertainty related to } \\
\text { agriculture, demands of } \\
\text { change }\end{array}$ & Ristiluoma and Sipiläinen, 2003 \\
\hline & $\begin{array}{l}\text { Low societal appreciation of } \\
\text { farming as a profession }\end{array}$ & Parry et al., 2005 \\
\hline
\end{tabular}




\begin{tabular}{lll}
\hline & Media criticism & $\begin{array}{l}\text { Booth and Lloyd, 1999; Parry et al., } \\
2005\end{array}$ \\
\hline $\begin{array}{l}\text { Environmental } \begin{array}{l}\text { Conditions } \\
\text { (2) Weather, natural conditions }\end{array} \\
\text { Deary et al., 1997; Alpass et al., 2004; } \\
\text { Parry et al., 2005; Glasscock et al., } \\
\text { 2006; Firth et al., 2007 }\end{array}$ \\
\cline { 2 - 3 } & $\begin{array}{l}\text { (2) Dangers in farm work; } \\
\text { injuries, deficiencies in } \\
\text { the work environment }\end{array}$ & $\begin{array}{l}\text { Deary et al., 1997; May, 1998a; } \\
\text { Melberg, 2003, Ristiluoma and } \\
\text { Sipiläinen, 2003; Parry et al., 2005 }\end{array}$ \\
\cline { 2 - 3 } & Physical environment & Fraser et al., 2005 \\
\cline { 2 - 3 } & Problems with farm animals & Glasscock et al., 2006 \\
\cline { 2 - 3 } & $\begin{array}{l}\text { Crisis of farm animal } \\
\text { diseases }\end{array}$ & Parry et al., 2005 \\
\hline $\begin{array}{l}\text { Personal factors (a } \\
\text { group outside those of } \\
\text { NIOSH, added by the } \\
\text { authors) }\end{array}$ & Health problems & May, 1998a; Simkin et al., 1998; \\
\cline { 2 - 3 } & Physical symptoms & Melberg, 2003 \\
\cline { 2 - 3 } & Grief & May, 1998a \\
\hline
\end{tabular}

\section{Interventions}

In this section we introduce examples of stress intervention projects. We also describe the farmers' social security system, occupational health services, and two examples of specific services, namely the 'Resource barn' (Voimavarariihi) and 'Support network for the rural population'.

In an American outreach programme known as the 'Farm Partners Program' (May, 1998b), farm families were linked to community-based services. The project included the training of surveillance volunteers and alerting of social agents to the needs of and services for farmers. An important focus was on prioritising treatment, needs assessment, counselling and referral services for farmers in distress. In an Australian intervention programme it was found important to have effective links between agricultural agencies and primary mental health care services (Fuller et al., 2009). In that study, rural financial counsellors had the most important role, not only as service providers but also as intermediaries in mental health service networks for farming families. Hossain et al. (2010) observed that providing training in mental health issues to rural service providers is beneficial, since training improves both the knowledge and confidence of the advisors.

Parry et al. (2005) described farmers as 'proud people', who may simply avoid asking for help. Thus, the problems are not expressed until the situation potentially develops into a conflict. Keating (1987) stated that farmers are 'high mastery individuals' and they are prone to see life as controllable. Based on this finding, she encouraged intervention actions to increase farmers' own resources through four strategies: a) positive thinking, b) seeking information, c) taking action and d) discussion with other persons.

a) Positive thinking Consider that you are able to manage demands; do not see situations as catastrophes. Evaluate your own emotions and reactions; try to reduce negative thinking. 
b) Seeking information The more you know about the demands, the more you will be able to manage them. Create a network of specialists or information sources around different topics. The Internet currently provides a rapid and feasible tool for needs of this kind. Particular expertise, for example concerning financial issues, may be needed on the farm (May, 1998b).

c) Taking action Do not acquiesce to problems; instead, try to do something. Improve time management, organize difficult tasks and develop problem-solving practices. If possible, avoid giving up, becoming irritated or treating problems with alcohol (Parry et al., 2005).

d) Discussion with other persons Find the positive elements of discussion with other persons; you may learn important facts and perhaps generate something useful together. Keating (1987) described social network as 'one of the best buffers against stress'; other farm entrepreneurs who really understand the situation on the farm may be helpful and supportive, because they face similar conditions themselves. Parry et al. (2005) concluded that social networks and own resources are the main elements to cope with stress. Church activities and 'personal spiritual practice' may also work as outside activities and response elements to stress. In addition, family support may provide important help during stressful periods.

Caldwell and Boyd (2009) reported how Australian rural families cope with stress caused by drought. The three main strategies resembled those of Keating (1987) above, namely a) problemfocused coping, b) psychological coping and c) collective coping, but as a negative strategy, denial was also observed. Denial may have poor long-term consequences, as a farming family may not be able to recognise the demands associated with change. Jones and Siegrist (1999) reported on a health promotion project by nursing students within rural communities in Kentucky. This project provided health information based on local needs and in local meeting places such as country markets. First, the students contacted local organizations and started to collaborate with farm women. The students surveyed health education needs, and stress was identified as among the 12 main health hazards and problems. In the following survey, stress management was identified as a key education topic. A special poster presentation (including 'Stress Management for Farmers') and possibilities to consult with experts were provided for farm entrepreneurs. The project was evaluated to provide 'sensitivity to rural culture' and specific problems of the farming population. Furthermore, Brumby et al. (2009) emphasized 'intersectoral collaboration and evidence-based health education' after a three-year intervention to change attitudes towards health among farm families.

Several difficulties may appear during intervention processes (Keating, 1987). It is important for the assistance staff to have a culturally appropriate attitude (May, 1998b). There may also be other traditional ways of thinking that may constitute lateral barriers, and during intervention programmes these types of 'norms' should somehow be handled. The prevailing social attitude may consider family difficulties as a part of private life and it may be thought that family members should be able to solve problems themselves (Keating, 1987). Farm entrepreneurs may simply have negative 
experiences of professionals outside the farm. Parry et al. (2005) described how formal organizations may be considered as 'enforcement' actors, and farmers may prefer local actors who have knowledge of the everyday life on farms. One third (34\%) of Finnish farm entrepreneurs have been found to have symptoms of exhaustion (Kallioniemi et al. 2009), which often include cynical attitudes. This type of thinking may have negative impacts, hindering the stress management process. Farm entrepreneurs may simply be busy and unable to spend time enjoying leisure activities and supportive social relationships (Parry et al., 2005). Moreover, the success of an intervention programme may be difficult to evaluate properly (May, 1998b).

\section{$\underline{\text { Intervention actions, examples from Finland }}$}

In everyday life, all benefits of the social security system can widely be understood as intervention actions, which support stressed farm entrepreneurs beyond their stressful periods. The Finnish social security system is based on the Nordic welfare state model, where the cornerstones are farranging public responsibility and tax funding. The farmers' social security system, including pensions, employment accident insurance and substitute assistance, is a unique system in Europe. Customers of the organization, the 'Farmers' Social Insurance Institution' (FSII), include farmers, fishermen, reindeer breeders and forest owners living in Finland. The FSII handles statutory pensions and employment accident insurance. Farmers are entitled to sickness benefit after three days if they are unable to work because of doctor-certified sickness or injury. Farmers can use substitute farm work services for annual leave, recreation or in cases of illness or injury. Crop production or animal husbandry farmers are both eligible to 26 days of annual leave if they are fulltime farmers and have at least four animal units. ${ }^{1}$ The farmer may also receive this assistance, for instance, for rehabilitation and occupational health activities, or adult education. Vocational rehabilitation is used to improve farmers' opportunities to continue in their current job or acquire training for a new occupation. The expenses for these services are partly covered by the state and the farmers themselves (Farmers' Social Insurance Institution, 2010a).

\section{Farmers' occupational health services}

Farmers' occupational health services (FOHS) are part of the Finnish public healthcare system and meant for promoting the well-being and work ability of farmers. In 2009, Finland had about 80000 insured farmers, $40 \%$ of whom were members of the voluntary occupational health services, which are mostly arranged in municipal health care centres (Farmers' Social Insurance Institution, 2010b). The protocol of the occupational health services is based on the law and on the Good Occupational Health Practice guidelines. In order to survey working conditions on the farm, farm visits are organized. An occupational health nurse and a local agricultural advisor, sometimes accompanied by an occupational health physician and/or a physiotherapist, should visit the farms of their clients to survey working conditions at least every four years. The assessment of working conditions on a farm should, where possible, include occupational hygiene measurements, for example noise and illumination, and chemical risk assessments. Mental well-being is assessed by observing the working conditions and the interaction between farmers and others who work or live on the farm

\footnotetext{
${ }^{1}$ An animal unit (AU) is a standardized measure of animals used for various agricultural purposes. A beef cow is the standard measure of an animal unit.
} 
(Kinnunen et al., 2007).

In addition, health examinations for farmers are carried out at least every second year. The health examination includes tests of work ability (Work Ability Index), burnout (Bergen Burnout Indicator, BBI-15), depression (Beck Depression Inventory, BDI-21) and alcohol consumption (Audit). There is no particular test for diagnosing stress, but the above tests provide a broad overview of the mental well-being of farmers. The examinations also include activities to promote work ability, guidance on rehabilitation and feedback for the farmers, such as improvements in working conditions or recommendations regarding the use of personal protectors. All clients with anomalous results can be referred to a medical specialist (Kinnunen et al., 2007). In 1999, the National Centre for Agricultural Health was founded through special legislation. It aims to improve the continuous development of Good Occupational Health Practice and the effectiveness and coverage of the FOHS.

In order to develop more efficient methods to improve working conditions on farms through the farmers' occupational health services, Heikkonen and Louhevaara (2003) developed 'empowered farmers' teams' to conduct more comprehensive farm visits. The aim was to increase the role of workers in problem solving and motivation as a part of active learning. The study was carried out in two periods, during 1998-1999 and 2000-2001. Team work among farm entrepreneurs enhanced discussions, utilizing 'common thinking', and farmers shared their experiences during these social farm visits. Over half of the resulting proposals were intended to improve ergonomic features on farms, because carrying, poor posture and a lack of equipment to relieve the workload were common issues. As a conclusion, the experiences were positive, because the 'teams' produced more proposals for improvements than the reference, ordinary farm visits, and the method used could be easily learned. However, the conventional farm visits of the FOHS were seen as more individual, broader and more systematic. Both systems therefore have their own positive elements.

\section{The 'Resource barn' service}

The 'Resource barn' (Voimavarariihi in Finnish), carried out by the Finnish extension service organization ProAgria, is a special service for farmers to evaluate their situation (Härkki-Santala and Pirkkalainen, 2008). The service was developed during 2004-2007 in a project funded by the European Social Fund and it is slowly spreading all over the country. The aim is to consider wellbeing comprehensively; the method is based on issues regarding physical and psychosocial working conditions, work ability, leadership and management, life-long learning, lifestyle issues, and the balance between work and private life. The framework of the service is based on the dimensions of work ability presented in Figure 2 (Ilmarinen et al., 2008). The 'Resource barn' service is intended for farmers who are expanding production, planning extensive changes to their farm or who want to quit farming permanently and receive farm closure compensation. With this service, farmers can assess the foreseeable risks and avoid burnout and harmful stress (Härkki-Santala and Pirkkalainen, 2008). 
[we are not allowed to reuse the picture; please utilize the mentioned reference]

Figure 2. Dimensions of work ability (Ilmarinen et al., 2008).

Source: Finnish Institution of Occupational Health 2010, AGE POWER.

The service process includes the provision of information on the services in advance, a questionnaire, two meetings and a feedback report. An agricultural adviser sends a personal questionnaire to the farmer two weeks before the first meeting. At the first meeting, the agricultural adviser talks through all the responses with the farmer, and together they work out the main problems affecting the farmer's well-being and work ability. The agricultural adviser writes a feedback report, which includes weaknesses, strengths, and the opinions of the entrepreneur and the adviser, a development plan, and proposals for progress. During the next visit, the adviser and the farmer agree on further actions and a follow-up timetable. The 'Resource barn' service resembles an alternative way to solve or prevent problems beforehand through consultation and guidance. The agricultural adviser is a coach who trains the farmer in how to solve problems and helps the farmer to deal with difficulties arising through changes. One challenge is that the workplace community on a farm is often the farmer's own family. Thus the relationship between the farming couple is important (Härkki-Santala and Pirkkalainen, 2008).

\section{Support network for the rural population}

An experimental helpline service for rural inhabitants was established in Finland during 1992-1996, organized by the Farmers Social Insurance Institution (FSII) and the Rural Women's Advisory Organisation (Sulin, 2001). After Finland became a member of European Union in 1995, farmers claimed that their workload, uncertainty regarding the future, and mental pressure significantly increased. Mental problems hindered survival and reinforced the uncertain situation in life (Leskinen, 2004). In August 1996, the Central Union of Agricultural Producers and Forest Owners organized a meeting following by the setting up of a project funded by the European Social Fund, entitled the 'Support network for the rural population'. First, they organized the training of voluntary support workers together with the Finnish Association for Mental Health. The network then expanded as these voluntary support workers trained local support people in municipalities. Within three years, the project had trained over 300 support persons (Sulin, 2001). Since 2001, the project has been financed by Finland's Slot Machine Association. About 60 voluntary support workers and 300 local support people work together to help the rural population. After basic training, they are also given comprehensive further training that covers diverse themes including the resources and risk factors of mental well-being, crisis situations and crisis behaviour, as well as an obligatory course on the supervision of voluntary work. The help is usually given via telephone conversations. Appointments and practical help are small in scale. One option is an Internet chat line. The most common problems involve human relations, such as problems among couples, depression, physical illness, loneliness, drug dependency and burnout. During recent years there have been about 3500-4000 contacts between supporters and their clients. 


\section{Conclusion}

The international agricultural product market has recently faced rapid changes, mainly due to globalization processes. The intensification of agriculture and at the same time the growing demands for ethical food production may place contradictory pressures on farmers. At present, farmers are at least partly used to adapting to variable weather conditions, but climate change is expected to severely affect agriculture in the future. We are therefore likely see significant fluctuations in the price for food products. All these features mean that farmers do not have a stable future. In Finland, as in many other countries, the average sizes of field areas and herds have increased, and some farms have sought alternative sources of income through farm diversification. EU membership has increased the share of subsidies in farm incomes and at the same time paper work, as well as new regulations and controls have mounted up. In this chapter we have presented Finland as an example, but international studies have also been reviewed.

Research findings concerning the prevalence of stress among farm entrepreneurs have been variable. As different data collection methods have been used, the results from separate studies are not directly comparable. Differing circumstances in different countries partly explain these differences; for example, the focus of discussion in society, a severe drought period or animal diseases may all affect stress symptoms among farmers. The prevalence of stress has been lower in telephone surveys compared with postal surveys, indicating that farmers may be more restrained in reporting their feelings during a telephone conversation. A study within European countries revealed that stress symptoms among different occupational sectors were highest among skilled agricultural and fishery workers, one-third (32\%) of whom were stressed. Strain among farm workers had also increased compared to the previous follow-up study in 2000. Furthermore, a large telephone survey in Finland in 2004 revealed that over a third (34\%) of full-time farm entrepreneurs had stress symptoms. Problems in social relationships, a higher educational level, and negative attitudes towards the EU, and physical health problems were all associated with these stress symptoms. Divorce, the physical strenuousness of agricultural work and economic problems further added to the risk of stress.

Stressors faced by farm entrepreneurs are presented in Figure 3, in which a farm-specific grouping is used. Based on published articles and research reports, the most often-mentioned stressors among farm entrepreneurs are the following:

1. The farm economy and regulations, farming bureaucracy, the amount of paper work, the political framework related to agriculture;

2. The weather, natural conditions and dangers in farm work; injuries, deficiencies in the work environment; and

3. New legislation.

Severe stress, often combined with other problems, may in an extreme case lead to suicide. Many researchers have reported that rural people do not actively seek help for mental health problems, because the culture may value self-sufficiency, or those who seek help for mental problems may be stigmatized. 


\section{NATURAL CONDITIONS}

-weather, natural conditions

-climate change

\section{FARM WORK}

-time pressure, work delays

-work overload

-machinery breakdowns

-increased technology and machinery use

-dangers in farm work; injuries

-work role conflicts

-problems with farm animals

-crisis of farm animal diseases

\section{ENTERPRISE}

-problems with the farm economy

-ongoing structural change

-demands of change

-uncertainty related to the future

of agriculture

\section{SOCIAL RELATIONSHIPS}

-shrinking social networks

-social conflicts

-farming family problems

-isolation

\author{
SOCIETY IN GENERAL \\ -new legislation, regulation \\ -increased paper work \\ -political framework \\ -demands of efficient production and \\ production ethicality, e.g. animal welfare \\ at the same time \\ -media criticism and low societal appreciation \\ of farming as a profession
}

PERSONAL SITUATION

-health problems

-physical symptoms

-ageing

-personal grief

Figure 3. Various stress factors faced by farm entrepreneurs

Several intervention studies have revealed that the development of effective networks is essential for handling and treating mental health problems among farmers. Researchers have also tried to identify feasible ways to reach those rural persons who struggle with mental health problems. In practice, this may include the training of rural financial counsellors in mental health issues or providing health information in the local market. Improving entrepreneurs' own capability to handle and cope with stressful periods was also recommended by means of positive thinking, seeking information, being active and supporting discussions with other persons. In everyday life, all benefits of the social security system can be widely understood as intervention actions, which support stressed farm entrepreneurs beyond their stressful periods. In Finland, farmers have a possibility use several kinds of intervention systems to improve their well-being. The social security system includes employment accident insurance and substitute assistance. The voluntary, well functioning farmers' occupational health service presently covers $40 \%$ of all insured farmers. The aim of another specific service for farmers, the 'Resource barn', is to prevent problems beforehand and evaluate the situation of farmers in order to maintain their well-being and work ability. A 
voluntarily-based 'Support network for the rural population' helps those recovering from mental health problems; the tools include telephone conversations and support through an Internet site.

In the future, we would encourage the development of measurement methods to research stress symptoms that would allow comparison between different studies. The numbers of respondents in previous different studies have varied and not all of the research results have been representative of the farming population in the country as a whole. Quantitative research methods have dominated in stress studies. In the future we encourage the use of qualitative methods in order to acquire a more complete picture of farming and stress. Follow-up studies would also be valuable, in addition to cross-sectional studies. Few intervention studies have been carried out that would enable the evaluation of existing methods or the development of new, feasible methods to improve the current situation among farmers. In addition, new research projects should make better use of previous studies as background information and a starting point. This cumulative approach may be stating the obvious, but we have observed this need when reviewing the literature.

More information is needed on the factors causing strain and stress among the farming population; this knowledge should include the associations of cultural, social and natural conditions within different countries. Long-term stress can lead to mental as well as physical illnesses. In examining this connection, diversified research on the prevalence of stress symptoms among the farming population is required. Knowledge of feasible methods to support and care for farm entrepreneurs is also needed. In particular, we underline the need for follow-up and intervention research in order to develop new and more effective support methods and organizations. Effective support has a positive impact on the success of the agriculture sector as a whole, but in addition has a positive impact on the social significance of agriculture in general. In order to manage farming and stress, there is a need for ongoing assessment and evaluation of the operational environment in agriculture and of the stressors faced by farmers, as well as future research actions and the practical implementation of support. These elements are presented as a circle in Figure 4. 


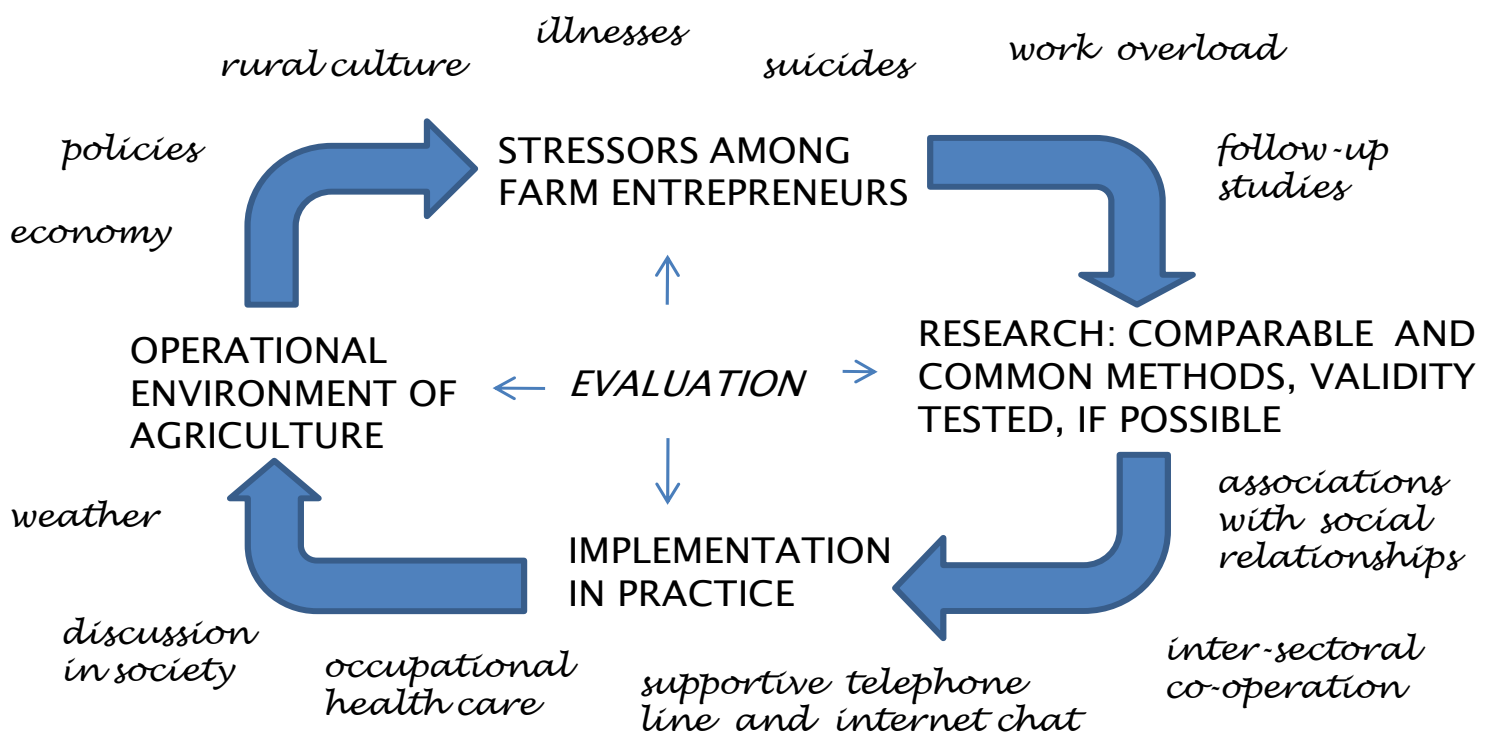

Figure 4. Management of stress among farm entrepreneurs.

Note: The schema includes assessment and evaluation of the operational environment, stressors, research actions and the practical implementation of support. Examples of factors related to stress among farm entrepreneurs are listed around the edge of the circle.

Good social relationships are a crucial element to avoid stress among farm entrepreneurs, and an adequate economic situation is also an important element of their well-being. Physical stress factors, including a poor work ability, are a serious issue and highlight the challenges facing health care systems and other networks.

\section{References}

Alpass, F., R. Flett, S. Humphries, C. Massey, S. Morriss and N. Long (2004), 'Stress in dairy farming and the adoption of new technology', International Journal of Stress Management, 11 (3), 270-281.

Alston, M. (2004), 'Who is down on the farm? Social aspects of Australian agriculture in the $21^{\text {st }}$ century', Agriculture and Human values, 21 (1), 37-46.

Becvarova, V. (2008), 'Issues of competitiveness of the present agriculture', Agricultural Economics -Zemedelska Ekonomika, 54 (9), 399-405.

Berkowitz, A. D. and W. Perkins (1985), 'Correlates of Psychosomatic Stress Symptoms Among Farm Women: A Research Note on Farm and Family Functioning', Journal of Human Stress, 11 (2), 76-81.

Booth, N. J. and K. Lloyd (1999), ‘Stress in farmers', International Journal of Social Psychiatry, 46 (1), 67-73.

Broom, D.M. (2010), 'Animal welfare: An aspect of care, sustainability, and food quality required by the public', Journal of Veterinary Medical Education, 37 (1), 83-88. 
Brumby, S.A., S.J. Willder and J. Martin (2009), 'The Sustainable Farm Families Project: changing attitudes to health', Rural and Remote Health. 9, 1012, (online), available at: http://www.rrh.org.au/publishedarticles/article_print_1012.pdf , accessed 1 December, 2010.

Caldwell, K. and C.P. Boyd (2009), 'Coping and resilience in farming families affected by drought', Rural and Remote Health, 9, 1088, (online), available at: http://www.rrh.org.au/publishedarticles/article_print_1088.pdf , accessed 7 December, 2010.

DeArmond, S. E., L. Stallones, P. Y. Chen and E.E. Sintek (2006), 'Depression and Somatic Symptoms within the Farming Community', Journal of Agricultural Safety and Health, 12 (1), 5-15.

Deary, I.J., J. Willock and M. McGregor (1997), ‘Stress in farming', Stress Medicine, 13 (2), 131-136.

Elo, A.-L., A. Leppänen and A. Jahkola (2003), 'Validity of a single-item measure of stress symptoms', Scandinavian Journal of Work, Environment and Health, 29 (6), 444-451.

Eloranta, Ville (2010), 'Hyvästit turhille teksteille', ('Farewell to unnecessary texts'), Helsingin Sanomat (newspaper article), 9 December, 2010. (In Finnish)

Enroth, A., P. Österman and H. Teräväinen (eds.) (2003), 'Laajentavien tilojen haasteet' ('The challenges of expansive farms'), Tieto tuottamaan 104, Keuruu, Finland: ProAgria Maaseutukeskusten Liiton julkaisuja nro 998. (In Finnish)

Farmers' Social Insurance Institution (2010a), 'Insured wellbeing from Mela', Maatalousyrittäjien eläkelaitos, Espoo, Finland, a brochure, available at: http://www.mela.fi/Esitteet/Insured_wellbeing_from_Mela.pdf , accessed 8 November, 2010.

Farmers' Social Insurance Institution (2010b), 'Mela-tilastot - Kuntatilastot', ('Statistics of the Farmers' Social Insurance Institution - municipal statistics'), Maatalousyrittäjien eläkelaitos, Espoo, Finland, available at: http://asp.hci.fi/mela/tilastot.nsf/Kuntatilastot_Vakuutukset? OpenView\& kunta=297\&vertailu=M\&tyyppi=U , accessed 5 November, 2010.

Firth, H.M., S.M. Williams, G.P. Herbison and R.O. McGee (2007), 'Stress in New Zealand farmers', Stress and Health, 23 (1), 51-58.

Fraser, C.E., K.B. Smith, F. Judd, J.S. Humphreys, L.J. Fragar and A. Henderson (2005), 'Farming and mental health problems and mental illness', International Journal of Social Psychiatry, 51 (4), 340-349.

Fuller, J., B. Kelly, G. Sartore, L. Fragar, A. Tonna, G. Pollard and T. Hazell (2007), 'Use of social network analysis to describe service links for farmers' mental health', Australian Journal of Rural Health, 15 (2), 99-106.

Fuller, J.D., B. Kelly, S. Law, G. Pollard and L. Fragar (2009), 'Service network analysis for agricultural mental health', MBC Health Services Research, 9, 87.

Glasscock D. J., K. Rasmussen, O. Carstensen and O. N. Hansen (2006), 'Psychosocial factors and safety behaviour as predictors of accidental work injuries in farming', Work \& Stress, 20 (2), 173-189.

Gregoire, A. (2002), 'The mental health of farmers', Occupational Medicine, 52 (8), 471-476.

Gunderson, P, D. Donner, R. Nashold, L. Salkowicz, S. Sperry and B. Wittman (1993), 'The epidemiology of suicide among farm residents or workers in five north-central states, 1980-1988', The American Journal of Preventive Medicine, 9 (1), 26-32.

Heikkonen, J. and V. Louhevaara (2003), 'Empowerment in farmers' occupational health services', Annals of the Environmental and Agricultural Medicine, 10 (1), 45-52.

Hossain, D., D. Gorman, R. Eley and J. Coutts, (2010), 'Value of Mental Health First Aid training of Advisory and Extension Agents in supporting farmers in rural Queensland', Rural and Remote Health 10, 1593-1601. 
Härkki-Santala, Maria and Minna Pirkkalainen (2008), 'Voimavarariihi. Valmentajan käsikirja' ('Resource barn trainer's handbook'), Kurikka, Finland: ProAgria Etelä-Savo and ProAgria Maaseutukeskusten liitto. (In Finnish)

Ilmarinen Juhani, Raija Gould, Jorma Järvisalo and Seppo Koskinen (2008), 'Diversity of Work Ability', pp.13 - 24, in: Raija Gould, Juhani Ilmarinen, Jorma Järvisalo and Seppo Koskinen (eds ), Dimensions of work ability, Results of the Health 2000 Survey, Finnish Centre for Pensions, The Social Insurance Institution, National Publc Health Institute, Finnish Institute of Occupational Health. Vaasa, Finland: Waasa Graphics Oy, Vaasa.

Information Centre of the Ministry of Agriculture and Forestry (2009), 'Yearbook of Farm Statistics', Helsinki, Finland: Edita Ltd. Available at: http://www.maataloustilastot.fi/sites/default/files/maatilatilastollinen_vuosikirja_2009.pdf Accessed 10 December, 2010.

Isometsä, E., M. Heikkinen, M. Henriksson, M. Marttunen, H. Aro and J. Lönnqvist (1997), 'Differences between urban and rural suicides', Acta Psychiatrica Scandinavica, 95 (4), 297-305.

Jones, M.S. and B. Siegrist (1999), 'Health Promotion for Farmers at the Country Market', Nurse Educator, 24 (5), 1618.

Judd F., H. Jackson, C. Fraser, G. Murray, G. Robins and A. Komiti (2006), 'Understanding suicide in Australian farmers', Social Psychiatry and Psychiatric Epidemiology, 41 (1), 1-10.

Kallio, Vesa (1997), 'Suomalaisen viljelijäväestön henkinen ilmapiiri' ( 'The mental atmosphere of the Finnish farm population'), Mikkeli : Helsingin yliopisto, maaseudun tutkimus- ja koulutuskeskus, Julkaisuja 53. (In Finnish)

Kallioniemi, M.K., A.J. K. Simola, H.-R. Kymäläinen, H.,T. Vesala and J.K. Louhelainen (2008), 'Stress among Finnish Farm Entrepreneurs', Annals of the Environmental and Agricultural Medicine, 15 (2), 243-249.

Kallioniemi M.K., A.J.K. Simola, H.-R. Kymäläinen, H.T. Vesala H.T. and J.K. Louhelainen (2009), 'Mental symptoms among Finnish farm entrepreneurs', Annals of Agricultural and Environmental Medicine, 16 (1), $161-170$.

Karasek, Robert. A. and Töres Theorell (1990), 'Healthy work: stress, productivity, and the reconstruction of working life', New York, USA: Basic Books.

Karhula, Timo and Harri Turunen (2009), 'Agricultural income', pp. 52-53, in: Niemi, Jyrki and Jaana Ahlstedt (eds.), 'Finnish Agriculture and Rural Industries 2009', MTT Agrifood Research Finland, Economic Research, Publications 109a, Vammala, Finland: Vammalan Kirjapaino Ltd.

Katila, Saija (2000), 'Moraalijärjestyksen rajaama tila: maanviljelijä-yrittäjäperheiden selviytymisstrategiat', ('Framed by moral order: The survival strategies of farm family businesses') Acta Universitatis Oeconomicae Helsingiensis A-174, Dissertation, Helsinki, Finland: Helsinki School of Economics and Business Administration. (In Finnish)

Keating, N.C. (1987), 'Reducing Stress of Farm Men and Women', Family Relations, 36 (4), 358-363.

Kerney, J. (2010), 'Food consumption trends and drivers', Philosophical Transactions of the Royal Society B, 365 (1554), 2793-2807.

Kettunen, Lauri (1994), 'Suomen maatalous vuonna 1993' ('Finnish agriculture year 1993'), Publications no. 73, Helsinki, Finland: Agricultural Economics Research Institute. (In Finnish)

Kinnunen, Birgitta, Jukka Mäittälä, Pirjo Pulkkinen-Närhi, Teuvo Siitonen, Kirsti Taattola and Marjut Weman (2007), 'Hyvä työterveyshuoltokäytäntö maatalousyrittäjien työterveyshuollossa' ('Good occupational health practice in farmer's occupational health services'), Helsinki, Finland: Finnish Institute of Occupational Health and the Ministry of Social Affairs and Health.

Kong, Y. and J. Zhang (2010), 'Access to farming pesticides and risk for suicide in Chinese rural young people', Psychiatry Research, 179 (2), 217-221.

Koskinen O., K. Pukkila, H. Hakko, J. Tiihonen, E. Väisänen, T. Särkioja, P. Räsänen (2002), 'Is occupation relevant in suicide?', Journal of Affective Disorders, 70 (2), 197-203. 
Leka S. and T. Cox (eds.) (2008), 'A Resource for Employers and Worker Representatives', Geneva: World Health Organization.

Leskinen, Jukka (2004), 'Saloseudulta EU-isännäksi - lypsykarjayrittäjät muutosmurroksessa. Seurantatutkimus 1997 2001', ('Dairy farmers in a period of transition. A follow-up study 1997-2001') Työ ja ihminen, Tutkimusraportti 24, Dissertation. Helsinki, Finland: Finnish Institute of Occupational Health. (In Finnish)

May, J.J. (1998a), 'Clinically Significant Occupational Stressors in New York Farmers and Farm Families', Journal of Agricultural Safety and Health, 4 (1), 9-14.

May, J.J. (1998b). 'The Farm Partners Program: Addressing the Problem of Occupational Stress in Agriculture', Journal of Agromedicine, 5 (2), 39-48.

Melberg, K. (2003), 'Farming, Stress and Psychological Well-being: The Case of Norwegian Farm Spouses', Sociologia Ruralis, 43 (1), 56-76.

Meltzer H., C. Griffiths, A. Brock, C. Rooney and R. Jenkins (2008), 'Patterns of suicide by occupation in England and Wales: 2001-2005’, The British Journal of Psychiatry, 193 (1), 73-76.

Ministry of Agriculture and Forstry (2008), 'Maatalouden tuki- ja valvontajärjestelmien yksinkertaistamista käsittelevän työryhmän loppuraportti' ('Final report; The Simplifying of Agricultural Subsidy and Controlling Systems'), Työryhmämuistio mmm 2008:12, available at:

http://www.mmm.fi/attachments/mmm/julkaisut/tyoryhmamuistiot/2008/5ApiNNgv6/ trm2008_7.pdf, accessed 8 December 2010. (in Finnish)

Monk, A. (2000), 'The Influence of Isolation on Stress and Suicide in Rural Areas: An international comparison', Rural Society, 10 (3), 393-403.

Moriondo, M, M. Bindi, Z.W. Kundzewicz, M. Szwed, A. Chorynski, P. Matczak, M. Radziejewski, D. McEvoy, A. Wreford (2010), 'Impact and adaptation opportunities for European agriculture in response to climatic change and variability', Mitigation and Adaptation Strategies for Global Change, 15 (7), 657-679.

Niemi, J. (2009a), 'Summary', pp. 5-7, in: J. Niemi and J. Ahlstedt (eds.), Finnish Agriculture and Rural Industries 2009, Agrifood Research Finland, Economic Research, Publications 109a, Vammala: Vammalan Kirjapaino Ltd.

Niemi, J. (2009b), 'Agricultural policy', pp. 45-49, in: J. Niemi and J. Ahlstedt (eds.), Finnish Agriculture and Rural Industries 2009, Agrifood Research Finland, Economic Research, Publications 109a, Vammala, Finland: Vammalan Kirjapaino Ltd.

Niemi, J. (2010), 'Livestock production', pp. 32-36, in: J. Niemi and J. Ahlstedt (eds.), Finnish Agriculture and Rural Industries 2010, Agrifood Research Finland, Economic Research, Publications 110a, Vammala, Finland: Vammalan Kirjapaino Ltd.

Niemi, J and J. Ahlstedt (eds.) (2006), 'Finnish Agriculture and Rural Industries 2006'. Agrifood Research Finland, Economic Research, Publications no 106a, Vammala, Finland: Vammalan Kirjapaino Ltd.

NIOSH (National Institute for Occupational Safety and Prevention) (1999), 'Stress at work', publication No. 99-101, Cincinnati, Ohio: Publications Dissemination, EID, available at: http://www.cdc.gov/niosh/docs/99-101/pdfs/99101.pdf, accessed 8 November, 2010.

Palmgren Helena, Simo Kaleva, Päivi Jalonen and Kaija Tuomi (2010), 'Naisyrittäjien työhyvinvointi' ('Women entrepreneurs' well-being at work'), Työ- ja elinkeinoministeriön julkaisuja, (Publications of Ministry of Employment and the Economy), Työ ja yrittäjyys (Employment and entrepreneurship) 5/2010, Helsinki, Finland: Edita Publishing Ltd.

Parent-Thirion, Agnès, Enrique Fernández Macias, John Hurley and Greet Vermeylen (2007), 'Fourth European Working Conditions Survey', European Foundation for the Improvement of Living and Working Conditions. Luxembourg: Office for Official Publications of the European Communities. 
Parry J., H. Barnes, R. Lindsey and R. Taylor (2005), 'Farmers, Farm Workers and Work-Related Stress', Research Report 362, Health \& Safety Executive, Suffolk, UK: HSE Books.

Patil, A. and K.V. Somasundaram (2010), 'Suicidal poisoning in Indian farmers - challenge to occupational health', in: RuralHealth 2010, Tirana 22/25 Sept '10, International Congress on Rural Health in Mediterranean and Balkan Countries. Book of abstracts.

Peltonen-Sainio, P., A. Rajala, H. Känkänen and K. Hakala (2009), 'Improving farming systems in northern European conditions', pp. 71-97, in: Sadras, V. and D. Calderini (ed.), 'Crop physiology: applications for genetic improvement and agronomy'. New York: Academic Press.

Peltoniemi, A. (2005), 'Työllisten työkyky vuonna 2004', ('The working capacity of the working population in 2004'), Työpoliittinen tutkimus nro 273, Helsinki, Finland: Ministry of Employment and the Economy. (In Finnish)

Perkiö-Mäkelä, M., P. Jokela and P. Manninen (2006b), 'Pitkäaikaissairastavuus ja oireet' ('Long-term illnesses and symptoms'), in: P. Rissanen (ed.) 'Työterveys ja maatalous Suomessa 2004' ('Occupational health and agriculture in Finland year 2004'). Kuopio: Finnish Institute of Occupational Health. (In Finnish)

Perkiö-Mäkelä, M., M. Hirvonen, A.-L. Elo, J. Ervasti, P. Huuhtanen, I. Kandolin, K. Kauppinen, T. Kauppinen, R. Ketola, K. Lindström, P. Manninen, J. Mikkola, K. Reijula, R. Riala, S. Salminen, M. Toivanen, M. Vilauksela (2006a), 'Työ ja terveys - haastattelututkimus 2006. Taulukkoraportti' ('Work and Health - Interview Study in 2006: Tabular Report'), Tampere, Finland: FIOH, Tampere. (In Finnish)

Piirainen, H., A.-L. Elo, E. Kankaanpää, H. Laitinen, K. Lindstöm K., T. Luopajärvi, P. Mäkelä, K. Pohjanpää, R. Riala (1997), 'Työ ja terveys -haastattelututkimus v. 1997: taulukkoraportti (Work and health - interview study in 1997: tabular report)'. Helsinki, Finland: Finnish Institute of Occupational Health. (In Finnish)

Piirainen, H., M. Hirvonen, A.-L. Elo, P. Huuhtanen, I. Kandolin, K. Kauppinen, R. Ketola, K. Lindström, S. Salminen, K. Reijula, R. Riala, M. Toivanen, M. Viluksela, S. Virtanen (2003), 'Työ ja terveys-haastattelututkimus 2003.

Taulukkoraportti' ('Work and health - interview study in 1997: tabular report'), Vammala, Finland: Työterveyslaitos. (In Finnish)

Pråhl-Ollila, M. (1995), 'Nuoret viljelijät maatalouden murroksessa', ('Young farmers and the structural change in agriculture'), Maatalousyrittäjien eläkelaitoksen julkaisuja 1/95, Espoo, Finland: Farmers' Social Insurance Institution. (In Finnish)

Pråhl-Ollila, M. (1997), 'Selviytyjiä, epätietoisia ja putoajia' (Survivors, uninformed and marginalized persons), Maatalousyrittäjien eläkelaitos, Espoo, Finland: Farmers' Social Insurance Institution. (In Finnish)

Raine, G. (1999), 'Causes and effects of stress on farmers: a qualitative study', Health Education Journal, 58 (3), 259270.

Rantamäki-Lahtinen, L. (2009), 'Rural enterprises', pp. 12-15, in: J. Niemi and A. Ahlstedt J (eds.), 'Finnish Agriculture and Rural Industries 2009', Agrifood Research Finland, Economic Research, Publications 109a, Vammala, Finland: Vammalan Kirjapaino Ltd.

Rissanen, Päivi (ed.) (2006), 'Työterveys ja maatalous Suomessa vuonna 2004 (Occupational Health and Agriculture in Finland in Year 2004)', Kuopio: Finnish Institute of Occupational Health. (In Finnish)

Ristiluoma, Riitta and Timo Sipiläinen (2003), 'Kannattavuuskirjanpitotilojen viljelijäkysely - vuosi 2002', (Survey among profitability accounting farms - year 2002), in: Riitta Ristiluoma, Timo Sipiläinen and Kalle Kankaanhuhta, 'Kirjanpitotilojen viljelijäkyselyn tulokset ja maksuvalmius', MTT:n selvityksiä 39, Helsinki, Finland: Data Com Finland Ltd. (In Finnish)

Saarni S. I., E. S. Saarni, H. Saarni (2008), 'Quality of life, work ability, and self employment: a population survey of entrepreneurs, farmers, and salary earners’, Occupational and Environmental Medicine, 65 (2), 98-103. 
Simkin S., K. Hawton, J. Fagg and A. Malmberg (1998), 'Stress in farmers: a survey of farmers in England and Wales', Occupational and Environmental Medicine, 55 (11), 729-734.

Simola, Ahti (2006), 'Henkinen hyvinvointi' ('Mental well-being'), in: P. Rissanen (ed.) (2006), 'Työterveys ja maatalous Suomessa vuonna 2004' ('Occupational Health and Agriculture in Finland in Year 2004'), Kuopio, Finland: Finnish Institute of Occupational Health. (In Finnish)

Simpson K., R. Sebastian, T. E. Arbuckle, C. Bancej and W. Pickett (2004), 'Stress on the farm and its association with injury', Journal of Agricultural Safety and Health, 10 (3), 141-154.

Smyth, B.M., H. Smyth, J. D. Murphy (2010), 'Can grass biomethane be an economically viable biofuel for the farmer and the consumer?', Biofuels, Bioproducts \& Biorefining 4 (5), 519-537.

Strieber, A. (2010), 'The 10 worst jobs of 2010', available at: http://www.careercast.com/ jobs/content/ten-worst-jobs2010-jobs-rated, accessed at: 23 November, 2010.

Sulin, Auli (2001), 'Maaseudun tukihenkilöverkko. Tukea ihmiseltä toiselle’ (Support network in rural areas), Espoo, Finland: Edita Oyj. (In Finnish)

Thomas, H. V., G. Lewis, D. Rh Thomas, R. L. Salmon, R. M. Chalmers, T. J. Coleman, S. M. Kench, P. MorganCapner, D. Meadows, M. Sillis, P. Softley (2003), Mental health of British farmers, Occupational and Environmental Medicine, 60 (3), 181-185.

Tirado, M.C., R. Clarke, L. A. Jaykus, A. McQuatters-Gollop and J. M. Frank (2010), Climate change and food safety: a review, Food Research International, 43 (7), 1745-1765.

TNS Opinion \& Social, 2010. 'Food-related risks', Special Eurobarometer 354/Wave 73.5., Brussels, Belgium.

Väre, M. (2009), 'Finnish farm', pp. 52-53, in: J. Niemi and A. Ahlstedt (eds.), Finnish Agriculture and Rural Industries 2009, Agrifood Research Finland, Economic Research, Publications 109a, Vammala, Finland: Vammalan Kirjapaino Ltd.

Vesala, Hannu, T. and Kari Mikko Vesala (2008), 'Suomalaisten viljelijöiden yrittäjä identiteetti 2001 ja 2006' ('Entrepreneur identity among Finnish farmers years 2001 and 2006'), p.82, in: Leena Rantamäki-Lahtinen (ed.), Maataloustieteen Päivät 2008 (Agricultural Science Days 2008), 10.-11.1.2008, Viikki, Helsinki, Suomen Maataloustieteellisen Seuran tiedote no 24, Helsinki, Finland: Copy-Set Oy. (In Finnish)

Vihinen, Hilkka (2004), 'Maatalous 90-luvun EU-Suomessa', (Agriculture of 90 decade in EU-Finland), pp. 21-30, in: Juha Nirkko and Kari Mikko Vesala, 'Kirjoituksia maan sydämeltä' (Writings from the heart of the countryside), Tampere, Finland: Tammer-Paino. (In Finnish)

Wager, Eija (2008), 'Paluumuuttajan päiväkirja' ('The diary of returnee'), Juva, Finland: Werner Söderström osakeyhtiö. (In Finnish)

Walker J. L. and L.J.S. Walker (1988), 'Self-reported stress symptoms in farmers', Journal of Clinical Psychology, 44 (1), 10-16.

Walker, L. S. and J. L. Walker (1987), 'Stressors and Symptoms Predictive of Distress in Farmers', Family Relations, 36 (4), 374-378.

Yip P. S. F., C. Callanan and H. P. Yuen (2000), 'Urban/rural and gender differentials in suicide rates: East and West', Journal of Affective Disorders, 57 (1-3), 99-106. 